\title{
Variation of Bioactive Compounds and Antioxidant Activity of Jujube (Ziziphus jujuba) Fruits at Different Stages of Ripening
}

\author{
Sina COSMULESCU ${ }^{1 *}$, Ion TRANDAFIR ${ }^{2}$, Violeta NOUR ${ }^{1}$, \\ Gheorghe ACHIM ${ }^{1}$, Mihai BOTU ${ }^{1}$, Olimpia IORDANESCU ${ }^{3}$
}

\author{
${ }^{1}$ University of Craiova, Horticulture Faculty, Department of Horticulture \& Food Science, 13 A.I. Cuza Street, 200585 Craiova, Romania; \\ sinacosmulescu@hotmail.com (*correspondingauthor); achimgheorghe555@yahoo.com; btmihai@yahoo.com; vionor@yahoo.com \\ ${ }^{2}$ University of Craiova, Sciences Faculty, Department of Chemistry, 107 Calea Bucuresti, \\ 200529Craiova,Romania;nelutrandafir@yahoo.com \\ ${ }^{3}$ Banat's University of Agricultural Sciences and Veterinary Medicine, Faculty of Horticulture, \\ 119 Calea Aradului, 300645 Timisoara, Romania; olimpia.iordanescu@yahoo.com
}

\begin{abstract}
Fruits of two jujube (Ziziphus jujuba Mill.) cultivars were collected at four stages of ripening and analyzed in terms of chemical compounds. The cultivars were grown under the climatic conditions of the Sub-Carpathian area Ramnicu-Valcea in Romania $\left(45^{\circ} 6^{\prime} 17^{\prime \prime} \mathrm{N}, 24^{\circ} 22^{\prime} 32^{\prime \prime} \mathrm{E}\right)$. Total phenols content, total flavonoids content, organic acids from jujube fruits and related antioxidant activities were investigated during the ripening stages. The antioxidant activity of alcoholic extracts was investigated by the 2,2'-diphenyl-1-picrylhydrazyl (DPPH) radical scavenging method. Total phenolic content was determined by using the Folin-Ciocalteu assay, while determination of flavonoids was done by aluminium nitrate colorimetric method, and organic acids were separated by reversed phase chromatography. The results obtained have indicated significant differences $(\mathrm{p}<0.05)$ found in bioactive compounds and antioxidant activity, depending on cultivars and ripening stage. Total phenolic content ranged from 1634.44 to $472.38 \mathrm{mg} \mathrm{GAE} / 100 \mathrm{~g}$ in methanolic extracts of the two varieties studied, while total flavonoids content ranged from 19.9 to $48.5 \mathrm{mg} \mathrm{QE} / 100 \mathrm{~g}$. As regards the influence of ripening stage, the results show that the highest antioxidant activity was recorded in the stage of white maturity. The impact of maturity stage was significant on organic acid distribution of jujube extracts, and ascorbic acid is the major organic acid found in jujube fruits, followed by malic acid and lactic acid. Jujube fruits are rich in bioactive compounds and can be a complement in human's healthy eating.
\end{abstract}

Keywords: antioxidant activities, jujube, organic acid, total flavonoids content, total phenols content

\section{Introduction}

Ziziphus jujuba is a fruit tree species native in Central Asia where is cultivated since ancient times and from where it was expanded to Asia Minor, Europe and America. In Romania, the Chinese date palms can be found in semispontaneous status in Dobrogea region (Ciocarlan, 2000), located between the Danube and the Black Sea; there are several places where the Chinese date palms exist in naturalized populations (Stanica, 2008). This fruit tree has been growing for several hundred years in Ostrov and Jurilovca villages and is called by local people "Dobrogea's olive tree" (Stanica, 2016). In the southern part of Romania there are appropriate natural conditions for Chinese jujube cultivation, the trees are extremely drought resistant and this species can be cultivated in integrated and organic farms and in small private gardens (Stanica, 2009). According to literature, Chinese date palm has a complex chemical composition that is useful to human health. The main biologically active components are vitamin $\mathrm{C}$, phenolics, flavonoids, triterpenic acids, and polysaccharides (Gao et al., 2013). Twelve flavonoids and nine phenolic acids were identified in ber (Ziziphus mauritiana) extract by LCDAD-MS analysis made by Memon et al. (2013). Investigations conducted by Li et al. (2007) showed that Chinese jujube contained $80.86-85.63 \%$ carbohydrate, $57.61-77.93 \%$ reducing sugar, $0.57-2.79 \%$ soluble fibre, 5.24-7.18\% insoluble fibre, $4.75-6.86 \%$ protein, $0.37-1.02 \%$ lipid, $17.38-22.52 \%$ moisture and $2.26-3.01 \%$ ash. Two phenolic acids (chlorogenic acid and caffeic acid) and three flavonoids (catechin, epicatechin and rutin) were determined by high-performance liquid chromatography in extracts of dried Chinese jujube fruit by Hudina et al. (2008). A total of 25 polyphenolic compounds were 
identified and classified as 10 flavan-3-ols, 13 flavonols, 1 flavanone, and 1 dihydrochalcone by Wojdylo et al. (2016) in four Spanish jujube cultivars. Jujube has a long history of usage as a fruit and remedy. Recent phytochemical studies of jujube fruits have shed some light on their biological effects, such as the anticancer, anti-inflammatory, antiobesity, immunostimulating, antioxidant, hepatoprotective, and gastrointestinal protective activities and inhibition of foam cell formation in macrophages (Gao et al., 2013; Abedini et al., 2016; Rajopadhye and Upadhye, 2016; Keerthi et al., 2016). In this paper, total phenols content, total flavonoids content, organic acid from jujube fruits and related antioxidant activities were investigated during the ripening stages in two jujube varieties grown under the climatic conditions of the Sub-Carpathian area Ramnicu-Valcea, Romania.

\section{Materials and Methods}

\section{Samples}

In this research the fruit composition of two jujube cultivars ('Ya Tsao', 'Ta-Jan Tsao') was analyzed. The fruits come from the experimental orchard of University of Craiova (SCDP Valcea), located in Sub-Carpathian area in Oltenia Region, Romania ( $\left.45^{\circ} 6^{\prime} 17^{\prime \prime} \mathrm{N}, 24^{\circ} 22^{\prime} 32^{\prime \prime} \mathrm{E}\right)$. Jujube samples were harvested in September 2016 at four edible stages of maturity that were determined based on the surface color, from white maturity (yellow skin color $=$ stage 1) to red maturity (having $100 \%$ red surface area $=$ stage 4 ). Jujubes were picked up randomly from different parts of several trees of the same species and were free from visible blemishes and diseases. After harvest, the fruits were immediately stored at $-20^{\circ} \mathrm{C} \pm 0.2^{\circ} \mathrm{C}$ until further use.

\section{Analytical methods}

The jujube samples were evaluated on the basis of their dry matter at $105^{\circ} \mathrm{C}$ and soluble solids content. Soluble solids were measured in the juice pressed from the whole fruit. Soluble solids concentration was measured using a digital refractometer and the results were expressed as percentages.

\section{Extraction procedure}

Pulp and whole fruit tissue (50g) from each cultivar have been finely chopped and then homogenized (using an IKA T-25 ULTRA-TURRAX mixer-homogenizer). Two extracts have been made: an aqueous extract used to quantify the organic acids and ascorbic acid, and a methanolic extract for extracting polyphenolic compounds and estimating their antioxidant properties. The extraction procedure was as follows: $2 \mathrm{~g}$ of product have been mixed with $20 \mathrm{~mL}$ water $/ 20 \mathrm{~mL}$ methanol, with $2 \%$ hydrochloric acid and put in sealed polyethylene flasks; and then were kept for 60 minutes at a temperature of $30{ }^{\circ} \mathrm{C}$ under the ultrasounds action.

\section{Chemicals and reagents}

Folin-Ciocalteu reagent (2N, Sigma-Aldrich), gallic acid (Sigma-Aldrich), anhydrous sodium carbonate (SigmaAldrich), methanol (Merck), 2,2-diphenyl-1-picrylhydrazyl (DPPH; Merck), ascorbic acid (Merck), quercetin (Merck), aluminium nitrate (Sigma-Aldrich), potassium acetate (Sigma-Aldrich), malic acid (Sigma-Aldrich), tartaric acid (Sigma-Aldrich), oxalic acid (Sigma-Aldrich), ascorbic acid (Sigma-Aldrich), and lactic acid (Sigma-Aldrich) were used in this experiment.

\section{Determination of total phenol content}

Total phenolics content in the extracts were colorimetrically determined with Folin-Ciocalteu reagent by using the method described by Cosmulescu et al. (2015). The absorbance of mixture was measured at $765 \mathrm{~nm}$ using an Evolution 600 UV/VIS spectrophotometer (Thermo Scientific, USA). Gallic acid was used to prepare the standard curve $(0-250 \mathrm{mg} / \mathrm{L})$. Gallic acid was used as reference standard and results were expressed as gallic acid equivalents in milligrams per $100 \mathrm{~g}(\mathrm{mgGAE} / 100 \mathrm{~g})$.

\section{Total flavonoids content}

Determination of flavonoids was done by aluminium nitrate colorimetric method described by Cosmulescu et al. (2015). Quercetin was used for preparing the standard curve $(0-100 \mathrm{mg} / \mathrm{L})$. The results were expressed as milligrams of quercetin equivalents per $100 \mathrm{~g}$ (mg $\mathrm{QE} / 100 \mathrm{~g})$.

\section{Anti-oxidant activity}

The capacity of scavenging of the 2,2-diphenyl-1picrylhydrazyl (DPPH) free radical was monitored according to the method reported by Cosmulescu et al. (2015). Anti-oxidant capacity was expressed in mg ascorbic acid equivalents per $100 \mathrm{~g}$ (mg acid ascorbic / $100 \mathrm{~g})$.

\section{Organic acid content}

The organic acids in the sample test solution were separated by reversed phase chromatography on a $250 \mathrm{~mm}$ $\times 4.6 \mathrm{~mm}$ i.d., $5 \mu \mathrm{m}$ particle Hypersil Gold aQ Analytical Column, of which they were detected by absorbance and quantified with external calibration graphs. The HPLC analysis was performed with a Surveyor Thermo Electron system comprising a vacuum degasser, Surveyor Plus LCPMPP pump, Surveyor Plus ASP autosampler and a diode array detector with $5 \mathrm{~cm}$ flow cell by using the method described by Nour et al. (2010). Integration, data storage and processing were performed by Chrom Quest 4.2 software. Organic acid content was expressed in mg per liter $(\mathrm{mg} / \mathrm{L})$.

\section{Statistical analysis}

Data have been subjected to analysis of variance (ANOVA) using Statgraphics Centurion XVI software (StatPoint Technologies, Warrenton, VA, USA). Differences were estimated with a multiple range test using the least significant difference (LSD) at $\mathrm{P}<0.05$.

\section{Results and Discussion}

\section{Analytical methods}

The results obtained have indicated significant differences $(\mathrm{p}<0.05)$ in dry matter content between ripening stage (Table 1). The dry matter contents of the 
136

fruits from jujube increased with maturity stage of the two varieties. The minimum dry matter contents were found in the first harvest (white maturity). The same variation was recorded for soluble solids content. Dry matter total content and soluble solids content in jujube cultivars ranged from 17.92 to $33.2 \%$ and 7 to $23 \%$, respectively, depending on maturity stage. For comparison, Koley et al. (2016) have reported similar values of soluble solids content for 12 commercial genotypes of Indian jujube (10 to 19\%).

\section{Total phenols content}

There are significant differences $(p<0.05)$ in total phenolics content between cultivars and ripening stage (Table 2). Total phenolic content ranged from 475.3 to $1634.4 \mathrm{mg} \mathrm{GAE} / 100 \mathrm{~g}$ in jujube fruits of the two cultivars studied. According to these results, total phenols content (mg GAE/100 g) of jujube was higher than that one found by Zhao (2014) in ethanolic extracts from seven cultivars of Chinese jujube (which ranged from 454.3 to 1298.9 GAE $\mathrm{mg} / 100 \mathrm{~g}$ ). A variation of total phenolics content was found by Li et al. (2007) in five cultivars of Chinese jujube (it ranged from 5.18 to $8.53 \mathrm{mg} / \mathrm{g}$ ), and found also by Wojdylo et al. (2016) in Spanish jujube fruits (1442 to $3432 \mathrm{mg} / 100$ g). All these results indicate that the content of total phenols is affected by cultivars, geographical conditions, horticultural factors, and more. The maturity stages had a significant influence in total phenolics content in jujube. The total phenolics content significantly decreased with the increase in maturity stages. In this present study the total phenolic content in jujube fruits decreased with maturity stage (2.6 times up to 3.1 times), which was in agreement with those reported previously for jujubes and other fruits. The same conclusion can be found in the study made by Wang et al. (2016) on jujube harvested in three edible stages of maturity. These results indicated that total phenolics content in jujube was clearly dependent on the ripening stage, and the highest concentrations were found within the more green stages. Wu et al. (2012) reported that uncoloring jujubes account as natural antioxidants with abundant proanthocyanidins.

\section{Total flavonoids content}

The results of flavonoids content, expressed as milligrams of quercetin equivalents per $100 \mathrm{~g}$ are presented in Table 2. Many significant differences $(p<0.05)$ are observed in total flavonoids content between cultivars and ripening stage among cultivars. Total flavonoids content ranged from 26.7 to $48.5 \mathrm{mg} \mathrm{QE} / 100 \mathrm{~g}$ in 'Ya Tsao' cultivar and between 19.9 and 34.6 in 'Ta-Jan Tsao' cultivar. The content of total flavonoids in genotypes of Indian jujube was also found to vary significantly, and the content ranged from 8.36 to $21.97 \mathrm{mg} \mathrm{CE} / 100 \mathrm{~g}$ (Koley et al., 2016). The total flavonoids content of jujube fruits decreased with maturity stage (1.7-1.8 times). In the research made by Wang et al. (2016) the content of total flavonoid contents was significantly reduced by 6 folds from white maturity to red maturity stage.

\section{Antioxidant capacity}

In terms of antioxidant activity, the results are presented in Table 2, and they ranged from 1154.6 to $1661.4 \mathrm{mg}$ ascorbic acid/100g. Antioxidant capacity, based on DPPH assay, is influenced by cultivar and ripening stage. Regarding the influence of ripening stage, the results show that the highest antioxidant activity was recorded in the stage of white maturity (stage 1). Similar results of decrease in DPPH radical scavenging activity along with the increasing maturity stage were also reported by others (Wang et al., 2016; Zozio et al., 2014).

\section{Organic acid content}

The amount of each organic acid found in jujube extracts is shown in Table 3. It was clear that the impact of maturity stage was significant $(p<0.05)$ on organic acid distribution of jujube extracts. As indicated by previous researchers (Wojdylo et al., 2016), ascorbic acid is the major organic acid found in jujube fruits, followed by malic acid and lactic acid. High content of ascorbic acid was recorded in red maturity stage in both varieties $(319.2-321.9 \mathrm{mg} / \mathrm{L})$. The same trend was registered for malic, lactic and tartaric acid. Oxalic acid was recorded in white maturity of fruits in

Table 1. Dry matter total content and soluble solids content of jujube fruits*

\begin{tabular}{|c|c|c|c|c|}
\hline \multirow{2}{*}{$\begin{array}{c}\text { Maturity } \\
\text { stage }\end{array}$} & \multicolumn{2}{|c|}{ Cultivar 'Ya Tsao' } & \multicolumn{2}{|c|}{ Cultivar 'Ta-Jan Tsao' } \\
\hline & Dry matter total content (\%) & Soluble solids content (\%) & Dry matter total content (\%) & Soluble solids content (\%) \\
\hline Stage 1 & $17.92 \pm 0.03^{\mathrm{a}}$ & $7.0 \pm 0.08^{\mathrm{a}}$ & $16.39 \pm 0.12^{\mathrm{a}}$ & $9.0 \pm 0.12^{\mathrm{a}}$ \\
\hline Stage 2 & $21.35 \pm 0.13^{\mathrm{b}}$ & $9.5 \pm 0.11^{b}$ & $18.56 \pm 0.16^{\mathrm{b}}$ & $13.5 \pm 0.08^{\mathrm{b}}$ \\
\hline Stage 3 & $22.21 \pm 0.08^{\mathrm{b}}$ & $10.5 \pm 0.07^{c}$ & $19.39 \pm 0.09^{c}$ & $15.0 \pm 0.09^{c}$ \\
\hline Stage 4 & $33.20 \pm 0.12^{\mathrm{c}}$ & $20.5 \pm 0.13^{\mathrm{d}}$ & $32.31 \pm 0.04^{\mathrm{d}}$ & $23.0 \pm 0.13^{\mathrm{d}}$ \\
\hline
\end{tabular}

${ }^{*}$ Data expressed as means \pm SE of three samples analysed separately. Different superscript letters within the same column indicate significant differences $(\mathrm{P}<0.05)$ among maturity stage

Table 2. Antioxidant activity, total phenolics content and total flavonoids content of jujube fruits*

\begin{tabular}{|c|c|c|c|c|c|c|}
\hline \multirow[b]{2}{*}{$\begin{array}{l}\text { Maturity } \\
\text { stage }\end{array}$} & \multicolumn{3}{|c|}{ Cultivar 'Ya Tsao' } & \multicolumn{3}{|c|}{ Cultivar 'Ta-Jan Tsao' } \\
\hline & $\begin{array}{c}\text { Total phenolic } \\
\text { content } \\
(\mathrm{mg} \text { GAE } / 100 \mathrm{~g})\end{array}$ & $\begin{array}{l}\text { Total flavonoid } \\
\text { content } \\
(\mathrm{mg} \mathrm{QE} / 100 \mathrm{~g})\end{array}$ & $\begin{array}{l}\text { Antioxidant activity } \\
\text { (mg acid ascorbic } \\
\qquad / 100 \mathrm{~g})\end{array}$ & $\begin{array}{c}\text { Total phenolic } \\
\text { content } \\
(\mathrm{mg} \text { GAE } / 100 \mathrm{~g})\end{array}$ & $\begin{array}{l}\text { Total flavonoid } \\
\text { content } \\
(\mathrm{mg} \mathrm{QE} / 100 \mathrm{~g})\end{array}$ & $\begin{array}{c}\text { Antioxidant activity } \\
\text { (mg acid ascorbic } \\
/ 100 \mathrm{~g})\end{array}$ \\
\hline Stage 1 & $1643.4 \pm 67.8^{\mathrm{d}}$ & $48.5 \pm 1.9^{\mathrm{d}}$ & $1661.4 \pm 50.5^{c}$ & $1269.6 \pm 45.1^{\mathrm{d}}$ & $34.6 \pm 1.2^{\mathrm{d}}$ & $1566.4 \pm 56.6^{c}$ \\
\hline Stage 2 & $936.6 \pm 31.2^{c}$ & $39.4 \pm 1.6^{c}$ & $1348.9 \pm 46.2^{b}$ & $704.8 \pm 23.9^{c}$ & $29.9 \pm 1.3^{c}$ & $1324.8 \pm 36.7^{\mathrm{b}}$ \\
\hline Stage 3 & $682.4 \pm 18.9^{b}$ & $31.1 \pm 1.2^{\mathrm{b}}$ & $1267.1 \pm 38.7^{\mathrm{b}}$ & $557.2 \pm 17.2^{\mathrm{b}}$ & $25.7 \pm 0.8^{\mathrm{b}}$ & $1266.4 \pm 41.3^{\mathrm{b}}$ \\
\hline Stage 4 & $529.5 \pm 23.2^{a}$ & $26.7 \pm 1.3^{a}$ & $1164.7 \pm 41.3^{\mathrm{a}}$ & $475.3 \pm 16.6^{a}$ & $19.9 \pm 0.7^{\mathrm{a}}$ & $1154.6 \pm 28.9^{a}$ \\
\hline
\end{tabular}

${ }^{*}$ Data expressed as means \pm SE of three samples analysed separately. Different superscript letters within the same column indicate significant differences (P < 0.05$)$ among maturity stage 
Table 3. Organic acid contents of jujube extract*

\begin{tabular}{|c|c|c|c|c|c|c|}
\hline Cultivar & Maturity stage & $\begin{array}{c}\text { Oxalic } \\
\text { (mg/L) }\end{array}$ & $\begin{array}{c}\text { Tartaric } \\
(\mathrm{mg} / \mathrm{L})\end{array}$ & $\begin{array}{c}\text { Malic } \\
(\mathrm{mg} / \mathrm{L})\end{array}$ & $\begin{array}{c}\text { Lactic } \\
(\mathrm{mg} / \mathrm{L})\end{array}$ & $\begin{array}{c}\text { Ascorbic } \\
(\mathrm{mg} / \mathrm{L})\end{array}$ \\
\hline \multirow{2}{*}{ 'Ya Tsao' } & white maturity & $92.3 \pm 3.2^{b}$ & $30.6 \pm 1.4^{a}$ & $106.1 \pm 4.2^{\mathrm{a}}$ & $105.1 \pm 3.8^{\mathrm{a}}$ & $280.4 \pm 12.2^{\mathrm{a}}$ \\
\hline & red maturity & $45.3 \pm 1.8^{\mathrm{a}}$ & $35.6 \pm 1.3^{\mathrm{b}}$ & $268.2 \pm 9.8^{\mathrm{b}}$ & $163.9 \pm 6.1^{b}$ & $321.9 \pm 14.3^{b}$ \\
\hline \multirow{2}{*}{ 'Ta-Jan Tsao' } & white maturity & $89.1 \pm 3.6^{\mathrm{b}}$ & $23.2 \pm 0.6^{a}$ & $130.7 \pm 5.4^{a}$ & $48.1 \pm 2.1^{\mathrm{a}}$ & $250.3 \pm 9.7^{a}$ \\
\hline & red maturity & $50.7 \pm 2.1^{\mathrm{a}}$ & $25.4 \pm 0.8^{b}$ & $305.6 \pm 12.5^{b}$ & $96.1 \pm 5.3^{b}$ & $319.2 \pm 13.8^{b}$ \\
\hline
\end{tabular}

${ }^{\overline{ }}$ Data expressed as means \pm SE of three samples analysed separately. Different superscript letters within the same column indicate significant differences $(\mathrm{P}<0.05)$ among maturity stage

both cultivars, the content ranging between 45.3 and 92.3 $\mathrm{g} / \mathrm{l}$. Gao et al. (2012) showed that ascorbic acid values were positively correlated with hardness in ten promising jujubes. The highest value in ascorbic acid of jujube fruits was recorded in harvested fruit at fully mature stage (637 $\mathrm{mg} / 100 \mathrm{~g} \mathrm{FW}$ ), by Moradinezhad et al. (2016).

\section{Conclusions}

The results presented in this study showed that total phenols content, total flavonoids content, organic acids of jujube fruits were all influenced by their developmental stage. Genotype too is influencing the composition of bioactive compounds in jujubes. Zizyphus jujube is good for direct consumption, and the fruit could be an important dietary source of natural antioxidants for prevention of diseases caused by oxidative stress.

\section{References}

Abedini MR, Erfanian N, Nazem H, Jamali S, Hoshyar R (2016). Antiproliferative and apoptotic effects of Ziziphus jujube on cervical and breast cancer cells. Avicenna Journal of Phytomedicine 6(2):142-148.

Ciocarlan V (2000). Flora ilustrata a României. Pteridophyta et spermatophyta. Editura Ceres, Bucuresti.

Cosmulescu S, Trandafir I, Nour V, Botu M (2015). Total phenolic, flavonoid distribution and antioxidant capacity in skin, pulp and fruit extracts of plum cultivars. Journal of Food Biochemistry 39(1):64-69.

Gao QH, Wu CS, Wang M (2013). The jujube (Ziziphus jujuba Mill.) fruit: a review of current knowledge of fruit composition and health benefits. Journal of Agricultural and Food Chemistry 61(14):33513363.

Gao QH, Wu C S, Wang M, Xu BN, Du LJ (2012). Effect of drying of jujubes (Ziziphusjujuba Mill.) on the contents of sugars, organic acids, $\alpha$ tocopherol, $\beta$-carotene, and phenolic compounds. Journal of Agricultural and Food Chemistry 60(38):9642-9648.

Hudina M, Liu M, Veberic R, Stampar F, Colaric M (2008). Phenolic compounds in the fruit of different varieties of Chinese jujube ( $Z i z i p h u s$ jujuba Mill.). The Journal of Horticultural Science and Biotechnology 83(3):305-308.

Keerthi M, Venkateswararao P, Devi PLA, Laxmi GKM, Venu P (2016). Phytochemical screening and anti helmenthic activity on the fruits of Ziziphusjujuba. The Pharma Innovation Journal 5(6):107-109.

Koley TK, Kaur C, Nagal S, WaliaS, JaggiS (2016). Antioxidant activity and phenolic content in genotypes of Indian jujube (Zizyphus mauritiana Lamk.).Arabian Journal ofChemistry 9(2):S1044S1052.
Li JW, Fan LP, Ding SD, Ding XL (2007). Nutritional composition of five cultivars ofChinese jujube. Food Chemistry 103(2):454460.

Moradinezhad F, Setayesh F, Mahmoodi S, Khayyat M (2016). Physicochemical properties and nutritional value of jujube (Ziziphus jujuba Mill.) fruit at different maturity and ripening stages. International Journal of Horticultural Science and Technology 3(1):43-50.

Memon AA, Memon N, Bhanger MI, Luthria DL (2013). Assay of phenolic compounds from four species of ber (Ziziphus mauritiana $\mathrm{L}$.) fruits: comparison of three base hydrolysis procedures for quantification of total phenolic acids. Food Chemistry 139(1):496-502.

Nour V, Trandafir I, Ionica ME (2010). HPLC organic acid analysis in different citrus juices under reversed phase conditions. Notulae Botanicae Horti Agrobotanici Cluj-Napoca 38(1):44 48.

Rajopadhye A, Upadhye AS (2016). Estimation of bioactive compound, maslinic acid by HPTLC, and evaluation of hepatoprotective activity on fruit pulp of Ziziphus jujuba Mill. cultivars in India. Evidence-Based Complementary and Alternative Medicine ID 4758734, http://dx.doi.org/10.1155/2016/4758734.

Stanica F (2009). Characterization of two Romanian local biotypes of Ziziphusjujube. Acta Horticulturae 840:259-262.

Stanica F (2016). Chinese dates (jujubes): a new promising fruit plant for Romania. In: Liu D, Ye X, Jiang Y (Eds). Chinese dates: A traditional functional food. CRC Press.

Stanica F, Vasile SA (2008). Chinese date - a new promising fruit plant for Romania southern areas. Acta Horticulturae 769:265-269.

Wang B, Huang Q, Venkitasamy C, Chai H, Gao H, Cheng N, Pan Z (2016). Changes in phenolic compounds and their antioxidant capacities in jujube (Ziziphus jujuba Miller) during three edible maturity stages. LWT-Food Science and Technology 66:56-62.

Wojdylo A, Carbonell-Barrachina ÁA, Legua P, Hernández F (2016). Phenolic composition, ascorbic acid content, and antioxidant capacity of Spanish jujube (Ziziphus jujube Mill.) fruits. Food Chemistry 201:307314.

Wu CS, Gao QH, Guo XD, Yu JG, Wang M (2012). Effect of ripening stage on physicochemical properties and antioxidant profiles of a promising table fruit 'pear-jujube' (Zizyphus jujuba Mill.). Scientia Horticulturae 148:177-184.

Zhao HX, Zhang HS, Yang SF (2014). Phenolic compounds and its antioxidant activities in ethanolic extracts from seven cultivars of Chinese jujube. Food Science and Human Wellness 3(3):183-190.

Zozio S, Servent A, Cazal G, Mbéguié-A-Mbéguié D, Ravion S, Pallet D, Abel $\mathrm{H}$ (2014). Changes in antioxidant activity during the ripening of jujube(Ziziphusmauritiana Lamk). Food Chemistry 150:448-456. 